\title{
The Oder-Neisse Line and Nation-Building in Poland since 1989. Phantom-Like Characteristics of Current Borders
}

\begin{abstract}
The Oder-Neisse line, Poland's western border since 1945, has played a prominent role in nation-building attempts since the fall of the communist regime. National-conservative politicians and likeminded actors have presented it as a frontier to protect the Polish nation against unwanted influences. The framing, in public and political discourses, of this Polish-German border as a frontier has waxed and waned. It seemed to have disappeared, only to retake centre stage in recent national-conservative rhetoric. A wide variety of Polish and international actors and institutions have been confronted with this 'haunting' effect of the Oder-Neisse line. In this case study, the author shows how it is not only former borders that can have phantom-like characteristics in the present, but current borders can be equally burdened with their own past.
\end{abstract}

Jasper Klomp is a PhD candidate at the Department of History at the University of Ljubljana.

\section{Introduction}

Several hours before the Berlin Wall fell on 9 November 1989, the West German chancellor, Helmut Kohl, of the Christian Democratic Union (Christlich Demokratische Union, CDU), had crossed the East German-Polish border by plane to Poland on his first official visit to an Eastern Bloc state in which communist rule had come to an end. In public and political discourses this border was, and still is, referred to as the Oder-Neisse line, named after the rivers Oder and Neisse that together have formed the largest part of the Polish-German border since 1945. In the scarce year between 9 November 1989 and the establishment of a united Germany on 3 October 1990, the Oder-Neisse line was the subject of heated arguments between Warsaw and Bonn. Polish politicians, other European governments, and political opponents in Germany criticized Kohl because he refused to reassure them regarding his view on the status of Poland's western border. Their concerns about the border had increased after the chancellor announced his 'Ten-Point Plan for Overcoming the Division of Germany and Europe' on 28 November 1989. For the Polish govern- 
ment, Kohl's plan lacked a 'point eleven' on the recognition of the Oder-Neisse line as the future geopolitical border between Poland and a united Germany. ${ }^{1}$ The discussions between Warsaw and Bonn resembled the Polish-West German wrangling in the period between the signing of the Potsdam Agreement in August 1945, when the territories east of the Oder-Neisse line were formally placed under Polish administrative control, and the signing of the Treaty of Warsaw in December 1970 by the then chancellor Willy Brandt of the Social Democratic Party of Germany (Sozialdemokratische Partei Deutschlands, SPD), in which the West German government recognized the Oder-Neisse line as Poland's western border 'now and in the future'. 2

The resurgence of the issue of the Oder-Neisse line in (geo)political discourse in 1989-90 was no coincidence. Ever since the emergence of the modern nation state, (attempted) changes in the leadership of states have been connected to ideas concerning the borders that separated or should separate an 'imagined community' from other communities, that is: nations. ${ }^{3}$ Such ideas do not necessarily originate at the domestic level. They can emerge as a reaction to (perceived) external pressures. Borders are, after all, a result of human behaviour: People do not only experience spaces, but they do try to (re)shape them according to their preferences. Highlighting the artificiality of geopolitical borders is of crucial importance when trying to grasp the use of borders as an identity-shaping tool. In this article, I focus on such practices with regard to the Oder-Neisse line since the fall of the communist regime in Poland.

The research project 'Phantom Borders in Eastern Central Europe' particular focused on the 'haunting' effects of former borders. Expanding the concept, I argue in this paper that the past of present borders can be equally 'haunting'. Since the Oder-Neisse line acted as a geopolitical border between two states both in the Cold War era and subsequently, it cannot be labelled a 'phantom border' in the sense of the aforementioned research project. The emphasis on 'haunting' effects is nevertheless very relevant for an analysis of the role played by the Oder-Neisse line in nation-building attempts in Poland since 1989. By pointing at the continued waxing and waning of the importance assigned to the Oder-Neisse line by a wide range of Polish politicians and like-

\footnotetext{
${ }^{1}$ Wanda Jarzabek, Shadows of Memory in Polish-German Relations (1989-2005), in: Kristin Kopp/Joanna Niżyńska, eds, Germany, Poland and Postmemorial Relations. In Search of a Livable Past, New York/NY 2012, 25-42, 28.

${ }^{2}$ University of Luxembourg, Centre Virtuel de la Connaissance sur l'Europe, Treaty Between the Federal Republic of Germany and Poland Concerning the Basis for Normalizing Their Mutual Relations (December 7, 1970), 3 March 2004, https://www.cvce.eu/content/ publication/1999/1/1/7f3363b0-2705-472a-b535-c42bd229f9e2/publishable_en.pdf. All internet references were accessed on 2 October 2019.

${ }^{3}$ Benedict Anderson, Imagined Communities. Reflections on the Origin and Spread of Nationalism, London, New York/NY 1983.
} 
minded actors, I argue that current borders, too, can have 'haunting' effects on societies and their identity discourses, as well as on (geo)political processes. 'Haunting' is used here to refer to characteristics that humans ascribe to ghosts or, more precisely, phantoms: The continual, though rather unexpected reappearance of past phenomena-not (only) physical borders, but also the meanings that people assigned to them in the past-has unforeseen, disquieting, or even harmful effects. The following case study is thus a plea for a broader understanding of 'phantom borders', one that is focused on the burdening of current borders with historical (spatial) 'phantoms'. ${ }^{4}$

First of all, a word on concepts. This study is about a formation referred to as the Oder-Neisse line. However, in the following I distinguish between 'lines', 'borders', and 'frontiers'. 'Lines' are understood as the outcome of a process in which humans contemplate the way in which land and water should be divided between states. 'Lines' per se do not necessarily have geopolitical meaning. Besides, they may or may not be constituted according to clear geographical phenomena, which is clearly demonstrated by the fact that the 'line' we are looking at here comprises (to a great extent) the River Oder and then, going south, the River Neisse, which is a tributary of the Oder. It is human thought that constructs such lines, rather than geographical phenomena as such. 'Lines' and 'borders' are closely linked. Without the human habit of creating borders it is unlikely that the rivers Oder and Neisse would ever have been referred to together as one single 'line'. Borders therefore are 'lines' that at some point in the past have officially been used to create a geopolitical separation between one piece of land or water and another. When such an act of separation is surrounded by discourse in which an 'us' versus 'them' rhetoric prevails, or renewed emphasis is placed on the separation, 'borders' can become 'frontiers'. The emphasis on the 'Oder-Neisse line' in this article is both related to its frequent use in public discourse, and to the potential of 'lines' to become the foundation of 'borders' and even frontiers, as explained above.

In the following, I first briefly introduce the theoretical connection between national identities and borders. Then I elaborate on a few aspects of the OderNeisse line's past, up to 1989, that are crucial for this study, such as issues of sovereignty, borders, and memory politics in Poland. Also, East and West German policies with regard to Poland and, more specifically, the Oder-Neisse line, are addressed. Following this, I explore the role of the Oder-Neisse line in nation-building practices in post-communist Poland, also factoring in the actions of a variety of perceived 'Others'. I thus do not attempt to present a comprehensive history of the Oder-Neisse line since the fall of the communist regime. Rather, my focus is on how the Oder-Neisse line served as an

\footnotetext{
${ }^{4}$ I would like to thank the anonymous reviewer who, by coming up with this phrase, helped me to express my thoughts more clearly.
} 
identity-shaping tool for Polish politicians and other public actors. To this end, I have conducted a qualitative analysis of public statements by prominent actors and newspaper articles. In other words, I focus not so much on the frequency with which the Oder-Neisse line is mentioned, but rather on the way in which it is framed. I also include bottom-up (civil) initiatives that counter these discourses in my analysis. However, these initiatives aim to, and sometimes succeed in 'softening' the take on geopolitical borders, while I am interested in revealing the ways in which borders were 'hardened', to the point of framing them, if that was deemed useful, as genuine frontiers.

\section{National Identities and Borders}

For any individual, carefully constructed representations of the past can create a sense of belonging to a group or large entity. In the case of nationalism, this is a nation or a nation state. The groups to which individuals feel attached are an expression of and shape their personal identities. A key aspect of any identity is the relationship between the 'Self' and the 'Other', in a Hegelian sense. Georg Wilhelm Friedrich Hegel in fact transferred this basic component of individual identity construction to the 'behaviour' of nation states: 'A state is as little an actual individual without relations to other states as an individual is actually a person without rapport with other persons. ${ }^{5}$ Hegel's inference is crucial in analyses on the shaping of national identities. As with all other identities, national identities are social constructs: (supposed) differences between 'us' (the people who form a nation) and 'them' (members of another nation) are underlined.

It is here that the concept of 'politics of memory' comes into play. In a Gramscian way, politicians, trade union leaders, activists, and other societal actors all strive for hegemony. In order to legitimise their policies, viewpoints, and actions, they all construct a certain representation of the past. ${ }^{6}$ In parliamentary democracies, the composition of the political elite is the clearest reflection of a hierarchy of viewpoints at a given moment. However, the memory politics of a political elite is not only a reflection of a certain mood in a country; it also tries to shape all citizens' interpretation of the past. In this process, the primary targets are children and teenagers, as their, as yet unshaped socialization provides the most fertile ground for teaching them (history) lessons in a way that suits those in power. A thorough understanding of a nation state's (assumed) national identity is also important with regard to political practice

\footnotetext{
${ }^{5}$ Georg Wilhelm Friedrich Hegel, Hegel's Philosophy of Right, translated with notes by Thomas Malcolm Knox, Oxford 1949, 212.

${ }^{6}$ Cf. Richard Ned Lebow, The Memory of Politics in Postwar Europe, in: Richard Ned Lebow et al., eds, The Politics of Memory in Postwar Europe, Durham et al. 2006, 1-39, 15.
} 
in a broader sense. Examples from around the world show the potential connections between national memory-building, on the one hand, and policy choices, on the other. ${ }^{7}$

For every kind of memory-personal, cultural, national, and so on-the dialogue about how past and present relate to each other needs to be a continuous one. National memory 'continuously negotiates between available historical records and current social and political agendas' ${ }^{8}$ Available stories and sources are interpreted and weighed up in order to ascertain their potential usefulness. Politicians use the method of 'cherry-picking': useful historical records are embraced, others become the victims of a process of 'active forgetting', which can turn out to be 'violently destructive when directed at an alien culture'. ${ }^{9}$ Political changeovers are accompanied by a need to construct a new national identity. The new political leadership can draw on an enormous volume of existing laws and policy documents, as well as speeches held by their predecessors. This is the 'administrative legacy' (or 'historical reservoir of knowledge') in a country: the preserved documentation of the activities of former governments, parliaments, heads of state, and so on. ${ }^{10}$ Although there was a gradual process of opening-up of societies in East Central Europe during the 1980s, the eventual actual loss of grip of the communist parties caused a feeling of uncertainty among citizens about what to expect from the future. As Veronika Bajt states, the 're-activation of national identities' in once communist countries came 'as no surprise':

'The nation is replacing the Communist state as the main institution providing people with a sense of stability and togetherness. [...] With the post-socialist era being seen as a radical social change, the re-activation of national identity seems to be important as a mobilizing force in order to establish the new states as credible political entities by creating a clear distinction from the "others".'11

7 Cf. Robert E. Harkavy, Defeat, National Humiliation, and the Revenge Motif in International Politics, International Politics 37, no. 3 (2000), 345-368, DOI: 10.1057/palgrave.ip.8890515; Ruth Wittlinger / Martin Larose, No Future for Germany's Past? Collective Memory and German Foreign Policy, German Politics 16, no. 4 (2007), 481-495, DOI: 10.1080/09644000701652490.

${ }^{8}$ Yael Zerubavel, Recovered Roots. Collective Memory and the Making of Israeli National Tradition, Chicago/IL et al. 1995, 5.

9 Aleida Assmann, Canon and Archive, in: Astrid Erll / Ansgar Nünning, eds, Cultural Memory Studies. An International and Interdisciplinary Handbook, Berlin 2008, 97-107, 98.

${ }^{10}$ Cf. Hannes Grandits, Gewandelte Wissensordnungen, neu gefasste Nostalgien. Zur Aneignung 'vergangener' Raummuster in Ostmittel- und Südosteuropa nach 1989, in: Béatrice von Hirschhausen et al., eds, Phantomgrenzen. Räume und Akteure in der Zeit neu denken, Göttingen 2015, 134-165, 164.

${ }^{11}$ Veronika Bajt, Invisible Nationalism, in: Sławomir Kapralski/Susan C. Pearce, eds, Reformulations. Markets, Policies, and Identities in Central and Eastern Europe, Warsaw 2000, 183-202, 199. 
Because of the arbitrary nature of nation-building practices and national identities, I adopt Maria Todorova's notion of 'legacy as perception', that is 'the articulation and rearticulation of how the entity is thought about at different times by different individuals or groups'. ${ }^{12}$

For political elites, geopolitical borders have a dual function. First, they delimit the body politic or the people contained within a given administrative unit, such as a nation state. Borders have a crucial influence on the specific set of laws any individual is confronted with. The second advantage of a border for politicians is its usefulness in the creation of a 'we' feeling. Like national identities and memories, borders are also social constructs: Despite their materiality, they are arbitrary lines on a map, which have been assigned meaning. In relation to today's state borders in East Central and Southeastern Europe, in the introductory chapter of the collective volume that first defined the concept of 'phantom borders', Hannes Grandits et al. drew attention to the newness of a considerable number of these borders. There are multiple examples of current nation states whose territories were part of different, sometimes even antagonistic entities in the past. The authors of the volume therefore assumed the 'existence of numerous phantom borders alongside the existing political borders in Europe today. ${ }^{\prime 13}$

The research network 'Phantom Borders in East Central Europe' was in fact established to reconsider the relationship between 'space' and 'time'. While the former tends to be framed as 'static', the latter seems subject to constant change. 'Phantom borders', on the contrary, are conceived as the result of the interaction between three operational layers defined along the lines of Henri Lefebvre's trinity of lived, perceived, and conceived space. ${ }^{14}$ In fact Lefebvre's categorisation, especially concerning his imagination of space, is crucial for our understanding of both former and present day borders, such as the OderNeisse line. In the words of Edward Said, 'there is no doubt that imaginative geography and history help the mind to intensify by dramatizing the distance and difference between what is close to it and what is far away'.15 Borders have, for example, served as discursive dividing lines, in fact as frontiers between 'civilization' and 'savagery', 'modernity' and 'backwardness', with one of the more conspicuous examples being the border between the Habsburg and the Ottoman Empires. ${ }^{16}$

\footnotetext{
${ }_{12}$ Maria Todorova, Imagining the Balkans, updated ed., New York/NY 2009, 198.

${ }^{13}$ Hannes Grandits et al., Phantomgrenzen im östlichen Europa. Eine wissenschaftliche Positionierung, in: von Hirschhausen et al., eds, Phantomgrenzen, 13-56, 13.

${ }^{14}$ Grandits et al., Phantomgrenzen im östlichen Europa, 39; Henri Lefebvre, The Production of Space, Malden/MA et al. 1991, 39-41.

${ }_{15}$ Edward W. Said, Orientalism, New York/NY 1979, 55.

${ }^{16}$ Grandits et al., Phantomgrenzen im östlichen Europa, 41.
} 
Canonical texts in the field of memory studies, such as Pierre Nora's Les Lieux de Mémoire (1984-1992) and Aleida Assmann's Erinnerungsräume. Formen und Wandlungen des kulturellen Gedächtnisses (1999) also focus on how perceptions of individual, regional, and national pasts are connected to spaces and their 'edges'. Similar to the approach of the research project on 'phantom borders', Assmann connects the renewed presence of former borders since the end of the Cold War to memory: 'The return of forgotten borders and images of the murderous enemy is connected to unleashed and politically instrumentalised memories.' ${ }^{17}$ What interests her is the question of whether a new polarization has taken place since the end of the Cold War, between societies to the west and east of the-officially-removed 'Iron Curtain'. She perceives this new schism as running between the west being 'prone to forgetting' and the east being 'prone to remembering'. However-following John Locke-remembering and forgetting cannot be disconnected from one another, which is why, as Assmann concludes, it is ultimately oversimplified to think in such polarized terms. Things are more complex. What is crucial here, however, is the political instrumentalization of borders in relation to stereotypes of a (murderous) enemy. ${ }^{18}$ As all memories serve the present and the future, Assmann advocates a critical reflection by historians on every act in which politicians mention the past. Only with such thorough reflection, can the misuse of the past for political purposes be made transparent and subsequently deconstructed. ${ }^{19}$

\section{The Oder-Neisse Line before 1989. Issues of Sovereignty, Borders, and Memory Politics}

In order to understand the most recent past, the history of the Oder-Neisse line and Polish-German relations up to 1989 need to be outlined. But maybe we actually need to go back even further: Poland's modern history has been characterized by a subsequent loss of sovereignty. In the late $18^{\text {th }}$ century, the Polish-Lithuanian Commonwealth, conceived as the First Polish Republic, disappeared from the European map. Its lands were split up between the Kingdom of Prussia, the Habsburg Monarchy, and the Russian Empire. At the end of the First World War, Poland entered into a period of new-found independence, when in 1918 the Second Polish Republic (II Rzeczpospolita Polska) was established. This period lasted only just over twenty years. On 1 September

\footnotetext{
${ }_{17}$ Aleida Assmann, Erinnerungsräume. Formen und Wandlungen des kulturellen Gedächtnisses, Munich 22006, 63.

18 Assmann, Erinnerungsräume, 63, 96.

19 Aleida Assmann, Der lange Schatten der Vergangenheit. Erinnerungskultur und Geschichtspolitik, Munich 2006, 274-275.
} 
1939, Nazi Germany invaded Poland. After the end of the Second World War, Poland found itself within the Soviet Union's (SU) sphere of influence.

Two aspects regarding the formation of and situation in the People's Republic of Poland (Polska Rzeczpospolita Ludowa, PRL) are of particular importance for the topic dealt with in this article. First, the postwar Polish state had very different geopolitical borders to interwar Poland. Since the Soviets refused to withdraw from the Eastern Borderlands (Kresy Wschodnie) they had annexed in 1939, the so-called Curzon Line became Poland's new eastern border. This 'line' was named after George Curzon, who served as the British Foreign Secretary between 1919 and 1924. Under his direction, a demarcation line was proposed as the border between the Second Polish Republic and the SU. The line put forward by Curzon was, however, not exactly the same as what came to be communist Poland's eastern border. Particularly in the south, the 'line' was moved westwards, excluding, among others, the now Ukrainian city of Lviv (Polish Lwów) from Polish territory. In order to compensate the Poles for the lost territories in the east, the Allied powers agreed to shift Poland's western border westwards as well. In this way, formerly German territories east of the rivers Oder and (Lusatian or Western) Neisse became part of Poland.

The second issue that needs to be discussed here is the problem of PolishGerman(-German) reconciliation. During the Cold War, it was an onerous task for the people in the PRL and the Federal Republic of Germany (FRG) to start a process of overcoming their shared painful past because of the ideological clash between 'East' and 'West'. As part of their legitimating and power-consolidating policies, the Polish United Workers' Party (Polska Zjednoczona Partia Robotnicza, PZPR) regularly pointed out the crimes committed by the Nazis and the Wehrmacht, as well as the successes of the Red Army in the 'Great Patriotic War'. The crimes perpetrated by the latter were hushed up, such as the Katyn massacre, in which an estimated 20,000 Polish (police) officers and members of the Polish intelligentsia were killed. This massacre was the biggest historical taboo in communist Poland. Another aspect of the Polish past which was hushed up, and one which would be of major importance in the debates on Poland's past that took place after the fall of the communist regime, was the relationship between Jewish and non-Jewish Poles. ${ }^{20}$ Moreover, as well as these two issues, also neglected in communist Poland's memory culture were the flight and expulsion of the Germans during the final stages of and after the Second World War. The same applies to the forced migration of Poles, who had to populate the former eastern territories of Germany (Ost-

${ }^{20}$ Michael C. Steinlauf, Bondage to the Dead. Poland and the Memory of the Holocaust, New York/NY 1997; Robert Blobaum, ed, Antisemitism and Its Opponents in Modern Poland, Ithaca/NY 2005. 
gebiete), which were 'polonized'. ${ }^{21}$ In the Federal Republic of Germany, on the other hand, a considerable share of the population was formed by 'homeland expellees' (Heimatvertriebene) from former German lands and other places in Central, Eastern, and Southeastern Europe. In the decades after the war, it were the Heimatvertriebene who actively lobbied against the formal recognition of the Oder-Neisse line.

For the German Democratic Republic (GDR), its recognition of the OderNeisse line as the border between the two states in July 1950 did not mark the end of discussions on this issue. ${ }^{22}$ Despite a similar emphasis by the authorities on the antifascist foundation of their respective communist states, it was virtually impossible for citizens in both states to jointly overcome their shared past until the border was opened in 1972. Concerning the many citizens of the GDR who had left the 'Ostgebiete' and crossed the border during the 1970s, it is claimed that the Poles that now lived there welcomed them as soon as they were convinced that the East Germans were only visiting, and not planning to return to their former homes. However, the visitors' greater wealth was one of the issues that, nevertheless, caused tensions during these contacts. ${ }^{23}$

From the mid-1960s onwards, the first small steps in the process of reconciliation between Poland and West Germany were taken. A significant action was the 'Pastoral Letter of the Polish Bishops to their German Brothers' sent in $1965 .{ }^{24}$ One of the most important components of the 'Neue Ostpolitik' implemented by Willy Brandt and his right-hand man Egon Bahr (SPD) was the acknowledgement by the FRG of the Oder-Neisse line as the German-Polish border in 1970. Consequently, the Oder-Neisse line lost its importance for the bilateral relations between the two states. Arguably, being one of the symbols of the divide between the 'Free World' and the Eastern Bloc, the inner German border became the most important border in Polish-West German political relations. The first cracks in the 'Iron Curtain', which appeared in the second half of the 1980s, led to a massive increase in the number of Poles with

\footnotetext{
${ }^{21}$ Gregor Thum, Uprooted. How Breslau Became Wrocław during the Century of Expulsions, Princeton/NJ 2003, 241-244.

${ }^{22}$ Sheldon Anderson, The Oder-Neisse Border and Polish-East German Relation. 19451949, The Polish Review 42, no. 2 (1997), 185-199, 198-199, www.jstor.org/stable/25778987.

${ }^{23}$ Katarzyna Stokłosa, Das Wunder an der Oder, Bundeszentrale für Politische Bildung, Dossier: Geschichte im Fluss. Flüsse als europäische Erinnerungsorte, 14 May 2012, http://www.bpb.de/geschichte/zeitgeschichte/geschichte-im-fluss/135933/das-wunder-ander-oder?p=0.

${ }^{24}$ Cf. Basil Kerski et al., eds, 'Wir vergeben und bitten um Vergebung'. Der Briefwechsel der polnischen und deutschen Bischöfe von 1965 und seine Wirkung, Osnabrück 2006.
} 
German predecessors leaving Poland. In 1988 and 1989, a total of 390,000 expellees (Aussiedler) migrated from Poland to the FRG. ${ }^{25}$

Despite of the imposition of martial law in Poland in 1981, causing fear by referring to the possibility of West German aggression was, according to Gregor Thum, 'no longer a viable political tool' for the Polish communists. ${ }^{26}$ However, at several instances during the 1980s, changing attitudes towards the Oder-Neisse line was a lived experience in the context of Polish-East German relations. Following a request by the East German authorities, in October 1980, visa free travel between Poland and the GDR was annulled with reference to the emergence of Solidarność and economic difficulties in both states. This complicated the continuation of the contacts between Polish and East German citizens in the border regions that had been established during the 1970s. ${ }^{27}$ Furthermore, the long-standing difference of opinion between Poland and the GDR on the state border running through the Pomeranian Bay developed into a diplomatic conflict in the period between 1985 and 1989. From the perspective of the Polish authorities, the GDR's claims regarding the territorial waters were related to the perceived need to underline East German sovereign statehood. Such a stance was not, however, in line with Polish national interests and ideas on a Polish national identity independent of German rule. ${ }^{28}$

\section{The Oder-Neisse Line and Nation-Building Practices in Poland after 1989}

In late November 1989, less than three weeks after the fall of the Berlin Wall, Kohl presented his aforementioned 'Ten-Point Plan'. This move suddenly made clear that the idea of German unification was, at least in the chancellor's eyes, an actual possibility. The decisiveness with which Kohl approached the situation that had emerged on 9 November was met with criticism both in the FRG and beyond. For instance, the Italian prime minister Giulio Andreotti was quoted in Der Spiegel: 'There are two German states, and two they shall remain.' Poland's non-partisan foreign minister Krzysztof Skubiszewski

\footnotetext{
${ }^{25}$ Bundesverwaltungsamt, (Spät-)Aussiedler und ihre Angehörigen. Zeitreihe 1950-2018, https://www.bva.bund.de/SharedDocs/Downloads/DE/Buerger/Migration-Integration/ Spaetaussiedler/Statistik/Zeitreihe_1950_2018.pdf?_blob=publicationFile\&v=2.

26 Thum, Uprooted, 388.

${ }^{27}$ Jonathan Murphy, Ending Cold War Divisions and Establishing New Partnerships. German Unification and the Transformation of German-Polish Relations, in: Katharina Gerstenberger/Jana Evans Braziel, eds, After the Berlin Wall. Germany and Beyond, New York/NY 2011, 105-125, 109; Stokłosa, Das Wunder an der Oder.

${ }^{28}$ Natalia Jackowska, The Border Controversy Between the Polish People's Republic and the German Democratic Republic in the Pomeranian Bay, Przeglad Zachodni, no. 3 (2008), 103-117, https://www.iz.poznan.pl/plik,pobierz,803,117719edb58a482a1261864c50dd596e/9-05.\%20 Jackowska.pdf.
} 
expressed a similar opinion: 'Self-determination is a nice idea, but with the Germans the situation is somewhat different. ${ }^{29}$ With regard to Skubiszewski's critical stance, it needs to be emphasized that it was preceded by a series of contradictory statements by Kohl regarding the acknowledgement of the OderNeisse line as the German-Polish border. The chancellor refused to assuage the doubts that had gained ground in Poland. Politicians in other states, and his political rivals in Germany, were concerned about his statements on the status of Poland's western border.

In the following, I describe the reactions of a range of Polish politicians to this delay of an all-German recognition of the Oder-Neisse line, perceived by them as unnecessary. As I show, it was this issue that made the Polish-German past an important point of reference for them. Polish national-conservatives already tended to interpret the Oder-Neisse line as a border that was traditionally contested by Germans. As a result of this episode, this stance was incorporated into postcommunist Poland's nation-building project from the very start. This laid the foundation for later periods during which Polish national interests were perceived to be under threat-or at least presented as such in order to promote nationalist rhetoric.

After the fall of the Berlin Wall, Kohl did not want to make what he called 'premature' decisions when it came to the Oder-Neisse line as the state border between a united Germany and Poland. He claimed that this would only be legally possible after German unification. ${ }^{30}$ Polish politicians publicly wondered what they could expect from the re-emergence of a big German state in the heart of Europe. ${ }^{31}$ The caustic comments made by Poland's political elite on Kohl's initial indecisiveness, and subsequently on his opinion that a German-Polish border treaty could only be signed after the approval of an all-German parliament, were made several months after Poland's first postcommunist government had come to power. As in any other state recently emerged from communist rule, creating a 'new' national identity was on the agenda. The scathing statements by Polish politicians should not only be interpreted as legitimate claims to security regarding Poland's territory, but also needs to be connected to this process of nation-building. In the course of the dispute, both the Polish and German side accused the other of stubbornness.

\footnotetext{
${ }^{29}$ In Angst vor der Einheit, Der Spiegel, 18 December 1989, http://www.spiegel.de/spiegel/ print/d-13497885.html.

${ }^{30}$ Cf. Debra J. Allen, The Oder-Neisse Line. The United States, Poland, and Germany in the Cold War, Westport/CT 2003, 287.

${ }^{31}$ Jacek Gawłowski, Kohlna huśtawce, Gazeta Wyborcza, 2 March 1990, http://www.archiwum. wyborcza.pl/Archiwum/1,0,6017703,19900302RP-DGW,KOHLNA_HUSTAWCE,.html; Oder-Neiße. Unehrlich und zweideutig, Der Spiegel, 5 March 1990, http://www.spiegel.de/ spiegel/print/d-13497039.html.
} 
Of great significance for the rapidly deteriorating Polish-German relations after the initial euphoria about the end of communism was the aforementioned high number of ethnic German emigrants (Aussiedler) that had left Poland for West Germany at the end of the 1980s. It was obvious that the ethnicity and origin of these individuals had not been forgotten in communist Poland. Apart from everything else, they were a symbol of Poland's westward shift after the Second World War and of the massive expulsions of ethnic Germans connected to this. The late socialist wave of emigration brought renewed attention to this 'origin story'. Since a large share of these 'expellees' (Heimatvertriebene) and their descendants in West Germany usually gave their vote to the conservative parties, that is Kohl's Christian Democratic Union or its Bavarian sister party, the Christian Social Union (Christlich-Soziale Union, CSU), it was not in Kohl's interests to provoke them. He linked a renewed acknowledgement of the Oder-Neisse line to emphasizing the fundamental rights of the German minority in Poland, something which was met with suspicion and even anger among Poles. ${ }^{32}$ In a speech in the Polish parliament in December 1989, foreign minister Skubiszewski questioned why the 'unlimited respect for the sovereignty and security of each state', which was part of Kohl's 'Ten-Point Plan', should only apply to the-at the time still-two German states, but not to Poland. ${ }^{33}$ Despite Skubiszewski's remarks, Kohl continued to resist the opinions of Washington, London, and Paris, and remained firm on his declaration that German unification and the recognition of the Oder-Neisse line were two sides of the same coin. He repeatedly emphasized that the Poles needed to wait for a decision by an all-German parliament. ${ }^{34}$ The upcoming elections in the five East German states (Länder) on 18 March 1990 undoubtedly influenced Kohl's stance. The Christian democrats feared the potential success of the farright Republikaner Party, whose leadership claimed that it was not possible to speak of German unification before its 1937 borders - which included the former German territories east of the Oder-Neisse line-were reinstated. ${ }^{35}$

In Poland, different interpretations regarding the question of whether Kohl actually opposed the acknowledgement of the border or whether electoral motives were the reason for his reluctant stance, created two opposing camps. Behind the scenes, foreign minister Skubiszewski advocated giving Kohl the time he needed to deal with the imminent electoral success of a party

${ }^{32}$ Oder-Neiße. Unehrlich und zweideutig.

${ }^{33}$ Joshua B. Spero, Bridging the European Divide. Middle Power Politics and Regional Security Dilemmas, Lanham/MD 2004, 65.

${ }^{34}$ Murphy, Ending Cold War Divisions, 114.

${ }^{35}$ Christina Schori Liang, 'Nationalism Ensures Peace'. The Foreign and Security Policy of the German Populist Radical Right After (Re)unification, in: Christina Schori Liang, ed, Europe for the Europeans. The Foreign and Security Policy of the Populist Radical Right, Aldershot et al. 2007, 148. 
like the Republikaner. On the other hand, Mieczysław Rakowski of the Social Democracy of the Republic of Poland (Socjaldemokracja Rzeczypospolitej Polskiej, SdRP) - who had served as prime minister in 1988-89 and had been the last first secretary of the Polish United Workers' Party (PZPR)-and other former communist politicians used Cold War rhetoric to warn about an assertive Germany. ${ }^{36}$ The eventual electoral victory of the CDU in the East German states (Länder) in March 1990 eased the situation to a certain extent. After German reunification, the Treaty on the Confirmation of the Polish-German Border and the Treaty of Good Neighbourship and Friendly Cooperation were signed by Poland and Germany in November 1990 and June 1991, respectively. ${ }^{37}$

In May 1990, the German president, Richard von Weizsäcker, visited Poland. In his first official statement he said:

'Between Poles and Germans, as in the whole of Europe, what matters is not the goal of recognizing borders so that they better demarcate us from one other. On the contrary: Borders should lose their divisive character. Borders should become bridges. We do not want to tear down the Berlin Wall in order to rebuild it at the Oder and the Neisse. ${ }^{38}$

However, in many ways the Oder-Neisse line could not-at least not continually-have a symbolic bridging function in post-Cold War Europe. During the period in which the two treaties were concluded, the Polish government agreed on the right of members of the German minority to speak German in public and to establish organizations. However, the request of the German government to recognize the dual nationality of these members of the German minority had, for now, been declined. Moreover, the proposed use of bilingual local names was also rejected. ${ }^{39}$ This strong stance of the Polish government was the first sign that the Polish-German past, and with it the Oder-Neisse line, could serve to strengthen a 'we' feeling among the Poles. Some of the Polish media also supported the government in this process. For example, the series of relatively small-scale protest actions by German ethnonationalists

\footnotetext{
36 Spero, Bridging the European Divide, 66.

37 Deutsch-polnischer Grenzvertrag. Vertrag zwischen der Bundesrepublik Deutschland und der Republik Polen vom 14. November 1990 über die Bestätigung der zwischen ihnen bestehenden Grenze, Potsdamer Konferenz, https://potsdamer-konferenz.de/dokumente/ deutsch-polnischer-grenzvertrag; Vertrag zwischen der Bundesrepublik Deutschland und der Republik Polen über gute Nachbarschaft und freundschaftliche Zusammenarbeit, Deutsch-Polnisches Jugendwerk, https://www.dpjw.org/fileadmin/user_upload/files/ 1264004326_nachbarschaftsvertrag.pdf.

38 'Aus Grenzen sollen Brücken werden'. Richard von Weizsäcker in Warschau. Auszüge aus seiner ersten Rede in Polen, Die Zeit, 4 May 1990, http://www.zeit.de/1990/19/ausgrenzen-sollen-bruecken-werden.

${ }^{39}$ Władysław Czapliński, The New Polish-German Treaties and the Changing Political Structure of Europe, The American Journal of International Law 86, no. 1 (1992), 163-173, 171172, DOI: $10.2307 / 2203147$.
} 
against the ratification of the Border Treaty was treated as a response from 'a lunatic fringe' in Germany. In Poland, however, these protests made front page news. ${ }^{40}$

The Constitution of the Republic of Poland is a case in point when it comes to the remarkable role the Oder-Neisse line has played from early postcommunist times onwards in fuelling ideas about the Polish nation (state). After considerable debate, the constitution came into effect on 17 October 1997. It represents a striking example of how Polish politicians applied the method of 'cherry-picking' when modelling a new national identity. In fact, it was the administrative legacies of the different former Polish states that were evaluated, and subsequently, in part, selected-as if they were pieces of a jigsaw puzzle-to construct Poland's national past. In the preamble, the term 'Third Republic' is used to refer to 'the best traditions of the First and Second Republic'. This invention of tradition was intended to send a message to both Polish citizens and the world: Poland was an independent state again, and placed high value on this fact. ${ }^{41}$

On the other hand, the constitution clearly distances independent Poland from communist Poland. For instance, with Article 23, the Third Republic indicates a permanent move away from the collectivization of agriculture in the communist era. In addition, Article 59 refers indirectly to and rejects the oppression of Solidarność in the 1980s. ${ }^{42}$ However, this embracement of the 'best traditions of the First and Second Republic' and rejection of the politics of the PZPR is not in keeping with the reference to borders in Article 26 on the safeguarding of Poland's territorial integrity by its armed forces: 'The Armed Forces of the Republic of Poland shall safeguard the independence and territorial integrity of the State, and shall ensure the security and inviolability of its borders.' ${ }^{43}$

\footnotetext{
40 Tomasz Kamusella, The Twentieth Anniversary of the German-Polish Border Treaty of 1990. International Treaties and the Imagining of Poland's Post-1945 Western Border, Journal of Borderland Studies 25, 3-4 (2010), 120-143, 135, DOI: 10.1080/08865655.2010.9695775.

${ }^{41}$ Both 3 May, the day the Constitution of the First Polish Republic was signed in 1791, and 11 November, the day Polish sovereignty was restored in 1918 (the Second Polish Republic) are public holidays in Poland today.

${ }^{42}$ Article 23: 'The basis of the agricultural system of the State shall be the family farm.' Article 59: 'The freedom of association in trade unions, socio-occupational organizations of farmers, and in employers' organizations shall be ensured.' Cf. National Assembly (Zgromadzenie Narodowe), The Constitution of the Republic of Poland of $2^{\text {nd }}$ April, 1997. As published in Dziennik Ustaw, no. 78, item 483, http://www.sejm.gov.pl/prawo/konst/ angielski/kon1.htm.

${ }^{43}$ Cf. National Assembly, The Constitution of the Republic of Poland.
} 
Ironically enough, thoughts about the location of the Polish state after the collapse of the communist regime were more in line with the preferences of Stalin, the oppressor, than with those of the Polish government-in-exile in London during and after World War Two. ${ }^{44}$ Although those who drafted the Polish constitution wanted-in line with the uti possidetis, ita possideatis ('as you possess, thus may you possess') common law principle-to stop the tradition of shifting Polish borders, they more or less embraced the fact that Poland had been a 'land on wheels' in the past. ${ }^{45}$ This is evidence of how arbitrary Polish politicians' approach to dealing with the past, as well as with the country's administrative legacies, in fact was. On the one hand, the state of affairs in the loathed communist Poland was actively rejected and/or ignored, and, on the other hand, the same was true of the oppositional stances to Poland's westward shift, as issued by the country's government-in-exile during the war. So the 'cherry-picking' approach aimed to adjust the past to the current state of affairs. In the case of postcommunist Poland's geopolitical borders, this is of course justifiable. And yet, such sober adjustment is something that has often been lacking in Polish politics since 1989.

\section{The Oder-Neisse Line as a Renewed Frontier. European Integration}

In Polish-German relations in the 1990s, the relevance of the Oder-Neisse line lost its sting after the signing of the treaties in 1990 and 1991 . Now the need to affirm Poland's 'Westernness' and 'Europeanness' was at the forefront and this was pursued with the accession to both the North Atlantic Treaty Organization (NATO) and the European Union (EU). After several disputes between Polish and German politicians between 1998 and 2002 about the conditions of Poland's EU accession, Helmut Kohl's successor Gerhard Schröder (SPD), governing a coalition of social democrats and the Green party, became an untiring advocate for an EU enlargement that included Poland. ${ }^{46}$ Another reason that the Oder-Neisse line played a less significant role in Polish-

\footnotetext{
${ }^{44}$ Cf. Richard C. Raack, Stalin Fixes the Oder-Neisse Line, Journal of Contemporary History 25, no. 4 (1990), 467-488, http://www.jstor.org/stable/260758; Matthew R. Schwonek, Kazimierz Sosnkowski as Commander in Chief. The Government-in-Exile and Polish Strategy. 1943-1944, The Journal of Military History 70, no. 3 (2006), 743-780, DOI: 10.1353/ jmh.2006.0194.

${ }^{45}$ Cf. Steven R. Ratner, Drawing a Better Line. Uti Possidetis and the Borders of New States, American Journal of International Law 90, no. 4 (1996), 590-624, 593, http://www.jstor. org/stable/2203988; Thomas Serrier, Phantomgrenzen und Erinnerungsräume. Zum Verhältnis von historischen Raumordnungen, sozialen Praktiken und Erinnerungskulturen, in: von Hirschhausen et al., eds, Phantomgrenzen, 107-133, 126.

${ }^{46}$ Cf. Marcin Zaborowski, Germany, Poland and Europe. Conflict, Cooperation and Europeanisation, Manchester 2004; Kopenhagener Gipfel. EU einigt sich mit Polen, Der Spiegel,
} 
German relations for most of the 1990s was the rejection by German intellectuals and a large proportion of the country's population of the memory politics of the Kohl administration, which shifted the focus to German victimhood. Important subjects of public debate during this period were, for example, the controversy around the reconfiguration of the Neue Wache, which, in 1993, became Germany's central memorial for the victims of war and dictatorship. Critics of the move pointed out that Kohl's preference for an enlarged replica of Käthe Kollwitz's pietà focused on German victims and, more importantly, disregarded the two largest groups of innocent victims, Jews and women. This debate coincided with the commercial success of Daniel Goldhagen's book Hitler's Willing Executioners in 1995, in which the author claims that the vast majority of the German people supported the antisemitic views of the Nazis between 1933 and 1945. The controversies around the Kohl government's attempts to interpret the past took centre stage at this time. ${ }^{47}$ However, as I will show in the following, the 'haunting' effects of the Oder-Neisse line returned to the fore in the late 1990s, initiated by Polish national-conservative actors concerned about what they perceived as a need to protect the Polish nation from unwanted influences. Initially these were certain German actors west of the Polish-German border, later the institutions of the EU, and most recently Muslim refugees.

Despite the aforementioned opposition in Germany to Kohl's memory politics, there were groups in the country who sought to focus increased public attention on German victimhood during Poland's EU accession process. At the core of this initiative stood the Association of Expellees (Bund der Vertriebenen, BdV), who proposed the formation of a Centre Against ExpulE sions (Zentrum gegen Vertreibungen, $\mathrm{ZgV}$ ). This Centre was to host a permanent exhibition, as well as an additional temporary exhibition or exhibitions, on the topic of expulsions in Europe during the $20^{\text {th }}$ century. The BdV is the umbrella organization for regional associations known as Landsmannschaften, in which expellees gathered and cooperated after their expulsion during and after World War Two, and in which some of their descendants also became active. In 2002, the German parliament decided to endorse the establishment of a 'European' Centre against Expulsions on the 'different causes, contexts and consequences' of the various expulsions in Europe that were to be commemorated. The issue was framed in this way with the aim of preventing the Heimatvertriebene from taking centre stage, and thus avoiding discord

13 December 2002, http://www.spiegel.de/politik/ausland/kopenhagener-gipfel-eu-einigtsich-mit-polen-a-226936.html.

${ }^{47}$ Cf. Bill Niven, Introduction. German Victimhood and the Turn of the Millennium, in: Bill Niven, ed, Germans as Victims, New York/NY 2006, 1-25, 5-7. 
with Germany's neighbours in East Central Europe. ${ }^{48}$ The formation of the 'Prussian Trustees' (Preußische Treuhand) at the end of 2000 added to these concerns. This organization (unsuccessfully) claimed that the 'expelling states', and especially Poland, owed the ethnic German expellees compensatory payments for the property they had lost. ${ }^{49}$

Despite the measures taken by the German parliament, leading Polish politicians already started to take a vehement stance towards their German colleagues before the final negotiations on Poland's EU accession in December 2002. In 2001, the League of Polish Families (Liga Polskich Rodzin, LPR) emerged as a new party on the right of the political spectrum. During the final year of the negotiation process, the LPR's leadership maintained that, after Poland's accession to the EU, the expellees and their descendants would claim back their lost houses and farms. ${ }^{50}$ Such statements put pressure on other Polish politicians to take a clear stance on their view of Germans in general. The LPR indulged in rhetoric about the Oder-Neisse line losing its function as a protective frontier once Poland became an EU member state, an approach which inevitably created mistrust. As a result, the Polish opposition towards the possibility of non-Polish residents with EU citizenship being able to purchase real estate in Poland was much fiercer than in the other EU accession candidates. Ultimately, an agreement was stipulated whereby Poland would be able to restrict the free movement of capital for an up to 12-year transitional period. Particular attention was paid to the acquisition of farmland, due to the Polish expectation that Germans with roots in the former German territories would have a special interest in this. ${ }^{51}$

Concerning the Centre against Expulsions, the Polish government expressed their preference for it to be located in Strasbourg, Sarajevo, or Geneva, rather than in Berlin, the former capital of Nazi Germany. It needed to be made very clear, they claimed, that the historical presentation was a comprehensive one, which emphasized that the expulsions of the Germans from Poland would not have happened if the Nazis had not occupied the country. The Polish press accused German chancellor Schröder of being a lackey of the Association of Expellees, and in particular its president Erika Steinbach, who was a member of the CDU at the time, and now supports the right wing Alternative for

\footnotetext{
48 Deutscher Bundestag, Beschlussempfehlung und Bericht des Ausschusses für Kultur und Medien (23. Ausschuss), 2 July 2002, http://dip21.bundestag.de/dip21/btd/14/096/1409661. pdf.

49 Preußische Treuhand GmbH \& Co. KG a.A., Die praktische Verwirklichung der Grundidee, http://www.preussische-treuhand.org/de/PVerwirklichung.html.

50 Kamusella, The Twentieth Anniversary of the German-Polish Border Treaty, 137.

51 Cf. Sergiusz Trzeciak, Poland's EU Accession, Abingdon, New York/NY 2012, 103-129.
} 
Germany party (Alternative für Deutschland, AfD). ${ }^{52}$ However, after meeting with Poland's prime minister Leszek Miller of the Democratic Left Alliance (Sojusz Lewicy Demokratycznej, SLD), Schröder concurred with the view that Berlin was not the right location for the Centre against Expulsions. ${ }^{53}$ This made little impression on national-conservative Poles who remained convinced that the Association of Expellees, and the Prussian Trust, aimed to frame themselves as the 'real victims' of the state's westward shift, and that, in so doing, these organisations blamed the Polish people of crimes in the form of the expulsions. Such blame in fact fitted perfectly with the Polish political elite's image of the country's past: a past characterized by victimhood and resistance. In September 2004, the Polish parliament began to pursue an initiative with the objective of 'fighting back' and as part of this issued a declaration calling for a renewal of reparation claims from Germany, in compensation for Poland's destruction by the Nazis. ${ }^{54}$

The bridge over the Oder River that connects Frankfurt, in Germany, with its former suburb Słubice, now a Polish municipality, was a powerful symbolic location during the celebrations of Poland's EU accession on 1 May 2004. However, in the subsequent years, Germany's and Poland's EU politics has diverged considerably. Poland fought tooth and nail to prevent any further delegation of state competences to the supranational level. The Polish parliamentary elections in September 2005 and the presidential elections one month later were both won by the Law and Justice party (Prawo i Sprawiedliwość, PiS) founded by the brothers Lech and Jarosław Kaczyński. The former was the president of Poland from December 2005 until his death in April 2010, and the latter was prime minister from July 2006 to November 2007. During these years, the Polish 'us-versus-them' rhetoric reached a new peak. The official reaction of the Polish government to a satirical article in the German newspaper Die Tageszeitung, in which president Lech Kaczyński was called a 'potato' (Kartof$\mathrm{fel}$ ), among other things, illustrates the ruthlessness with which PiS acted: Die

\footnotetext{
${ }^{52}$ Cf. the telling cover photograph of Wprost, 21 September 2003, https://www.wprost. pl/tygodnik/archiwum/1086/Wprost-38-2003.html; as well as Piotr Kudzia/Cezary Gmyz, Bomba Steinbach, Wprost, 28 September 2003, https://www.wprost.pl/tygodnik/49710/ Bomba-Steinbach.html.

${ }^{53}$ Vertriebenen-Zentrum. Schröder und Miller wollen europäische Lösung, Der Spiegel, 22 September 2003, http://www.spiegel.de/politik/deutschland/vertriebenen-zentrumschroeder-und-miller-wollen-europaeische-loesung-a-266741.html.

${ }^{54}$ Kriegsreparationen. Entrüstung über polnischen Parlamentsbeschluss, Der Spiegel, 10 September 2004, https://www.spiegel.de/politik/ausland/kriegsreparationen-entruestungueber-polnischen-parlamentsbeschluss-a-317637.html. However, the Polish government declined the declaration, for it being 'in breach of Poland's international obligations', cf. Kamusella, The Twentieth Anniversary of the German-Polish Border Treaty, 137.
} 
Tageszeitung was compared to the Nazi newspaper Der Stürmer. ${ }^{55}$ A couple of days after this initial reaction, Jarosław Kaczyński stated in an interview with the Polish magazine Wprost that it was up to the Germans to improve the relationship with their neighbour, since the Poles had not offended anyone. Moreover, Jarosław Kaczyński also proposed a change in Poland's foreign policy. In his view, the foreign policy measures of the other large EU member states were based solely on domestic interests, and Poland should do the same. ${ }^{56}$

This position hints at the fact that, even though Germany remained the most popular target, both the rest of western Europe and Russia were verbally attacked, too. ${ }^{57}$ What is more, PiS politicians accused other Polish politicians of not making a clear break with the communist era, and therefore started to use the notion of a 'Fourth Polish Republic'. This was done to insinuate that the PiS leadership represented a new beginning for the Polish nation. It also meant that the 'cherry-picking' from Poland's administrative legacy started anew. As PiS's electoral defeat in the parliamentary elections of October 2007 indicated, however, the Kaczyński brothers had overplayed their hand with their provocative rhetoric and foreign policy, at least for the time being. In the years that followed, the Oder-Neisse line once again ceased to take centre stage in Polish politics and public discourse. Instead, the governments dominated by the Civic Platform (Platforma Obywatelska, PO) worked towards Poland and Germany playing a pioneering role in Europe. ${ }^{58}$

After the electoral success of PiS in 2015, Warsaw embarked on a conflict-oriented foreign policy yet again, and once more, the Oder-Neisse line came to the fore. It is of significance that during the presidential elections of 2015, PiS candidate Andrzej Duda won most districts in the east of the country, whereas PO candidate Bronisław Komorowski won most districts in the west of Poland, where people had more contact with the citizens of other EU member states-

\footnotetext{
${ }_{55}$ Peter Köhler, Polens neue Kartoffel, Die Tageszeitung, 26 June 2006, http://www.taz.de/ !413444/; Polnische Präsidentenkanzlei vergleicht 'taz' mit 'Stürmer', Frankfurter Allgemeine Zeitung, 6 July 2006, http://www.faz.net/aktuell/politik/ausland/satire-ueber-kaczynskipolnische-praesidentskanzlei-vergleicht-taz-mit-st uermer-1357255.html.

${ }^{56}$ Igor Janke, W żadnej sprawie nie ustąpię, Wprost, 16 July 2006, https://www.wprost.pl/ tygodnik/92362/W-zadnej-sprawie-nie-ustapie.html.

${ }_{57}$ Cf. Wolfram von Scheliha, Die List der geschichtspolitischen Vernunft. Der polnischrussische Geschichtsdiskurs nach 1989, in: Etienne François et al., eds, Geschichtspolitik in Europa seit 1989, Göttingen 2013, 221-263.

${ }_{58}$ Cf. Donald Tusk, Rede von Premierminister Donald Tusk (Deutsch), Der internationale Karlspreis zu Aachen, 13 May 2010, http://www.karlspreis.de/de/preistraeger/donaldtusk-2010/rede-von-premierminister-donald-tusk-deutsch; Christian Schweiger, Poland, Variable Geometry and the Enlarged European Union, Europe-Asia Studies 66, no. 3 (2014), 394-420, 398, DOI: 10.1080/09668136.2013.869898.
} 
most notably Germans - and where numerous Polish-German initiatives 'from below' had countered the exclusivism of PiS's 'restorative nostalgia'. ${ }^{59}$

This time the presumed threat from Germany is not personified by (descendants of) ethnic German expellees and emigrants, but by refugees from Syria and other countries of the Middle East as well as Africa. The massive influx of refugees to Germany in the wake of chancellor Angela Merkel's (CDU) 'We will manage this' (Wir schaffen das) statement represented, according to PiS politicians, a health and security threat to Europeans, and specifically the Poles. ${ }^{60}$ Accordingly, the PiS-led government has rejected EU relocation plans for refugees. In a peculiar twist, the Oder-Neisse line once again becomes the frontier protecting the Polish nation from unwanted and supposedly destructive influences. The cooperation between PiS and Hungary's prime minister Viktor Orbán focuses on the maintenance of national sovereignty: 'There is no free Europe without nation states', said Orbán in October 2016 with the Polish president Duda at his side. ${ }^{61}$ A concentration of power in Brussels that limits the legislative capacities of national governments-dubbed 'Sovietization' by the Hungarian prime minister-has, in fact, come to be seen as a threat by various parties on both the right and the left of the political spectrum in many European countries. However, until the 2018 general elections in Italy, Eurosceptic parties were able to secure a majority of seats only in former communist countries. In 2007 in his seminal Postwar, Tony Judt described historical memories in Europe as 'deeply asymmetrical'. ${ }^{62}$

${ }^{59}$ For a map of the election results cf. Robert Wielgórski, Wybory prezydenckie w Polsce w 2015 roku. Wyniki II tury z podziałem na powiaty, 25 May 2015, https://commons. wikimedia.org/wiki/File:Wybory_prezydenckie_2015_II_tura_mapa.png. I borrow the term 'restorative nostalgia' from Svetlana Boym, The Future of Nostalgia, New York/NY 2001, 41: 'Restorative nostalgia [...] proposes to rebuild the lost home and patch up the memory gaps. [...] This kind of nostalgia characterizes national and nationalist revivals all over the world, which engage in the antimodern myth-making of history by means of a return to national symbols and myths'.

${ }^{60}$ Bart Bachman, Diminishing Solidarity. Polish Attitudes toward the European Migration and Refugee Crisis, Migration Policy Institute, 16 June 2016, https://www.migrationpolicy. org/article/diminishing-solidarity-polish-attitudes-toward-european-migration-and-refugeecrisis. Not only Poland's western border is used to prevent refugees from entering the country, but also the Polish-Belorussian border, cf. Poland: Asylum Seekers Blocked at Border, Human Rights Watch, 1 March 2017, https://www.hrw.org/news/2017/03/01/poland-asylumseekers-blocked-border.

${ }^{61}$ Hungary Must Fight 'Sovietization' of Europe by Defending Borders Against Refugees-Orban, Russia Today, 24 October 2016, https://on.rt.com/7sr9.

${ }_{62}$ Tony Judt, Postwar. A History of Europe Since 1945, London 2007, 826. 


\section{Conclusion}

It is not only former borders that can have 'haunting' effects on the present-day world. An analysis of the historical meanings that have been attached to the Oder-Neisse line in the process of constructing and maintaining a national identity in Poland since 1989 emphasizes that Polish national-conservative actors have and indeed still are attempting to constrain both the Poles who reject their extensive use of 'us' versus 'them' rhetoric and those who serve as the 'Other' in this rhetoric. Interestingly, the Poles who reject the national-conservative identity engineering mostly live near the Oder-Neisse line and have thus had more direct contact with the people living on the other side of the border, in Germany. Due to its function as a geopolitical border with changing qualities over time, the Oder-Neisse line has developed all the characteristics of a phantom border even while in existence. It disappeared from public discourse several times, only to make a comeback in the rhetoric of politicians, journalists, and other societal actors seeking to emphasize how perpetually endangered Polish sovereignty and values are. They frame the Polish-German border as a frontier that should keep 'us' (Poles) and 'them' (Germans, older EU member states, Europhiles, refugees) apart.

The instrumentalization of the Oder-Neisse line in nation-building efforts in Poland since 1989 has been characterized by inconsistency. If Western societies attached meaning to the former border of the Ottoman Empire as a marker between Western 'civilization' and Oriental 'savagery', ${ }^{63}$ the border between Poland and Germany has rather been used in the periods of PiS-dominated governments to suggest a frontier that should stop the spread of 'savagery' from Western to East Central Europe. Polish national-conservative politicians take the ingredients of traditional and catholic values from the historical legacy 'pool' in order to define civilization.

In addition to this, in Poland, given the country's legacy of a repeated struggle to regain or maintain its position on the European map, a number of politicians have wholeheartedly embraced the fact that borders are a human construct in the arbitrary process of nation-building. This is exemplified by the fact that national-conservative politicians have declared Syrian refugees, among others, as unwelcome on Polish territory. Such stances seem rather peculiar, given that both before and after Poland's westward shift as a consequence of the Second World War, the much-praised anticommunist government-in-exile did not think that a large part of the newly-gained western territories were inherently Polish.

${ }^{63}$ Todorova, Imagining the Balkans. 
Thus, in the case of the Oder-Neisse line, Grandits' notion of a 'new "post-socialist" knowledge order', in which borders are understood as matters that need to be legitimated 'historically', is at once both apt, and not so apt. ${ }^{64} \mathrm{On}$ the one hand, the geographic position of the Polish-German border could only be justified in the context of defining Poland's western border in the Cold War era, that is as a border which was more or less imposed on the Poles by the Soviet Union and the other Allied countries. At the time, the Oder-Neisse line did not exactly fit in with Polish ideas on the location of the Polish state. On the other hand, the periods in the past when Poland was not a sovereign state have been constantly referred to in order to emphasize the importance of an independent Polish state. This extremely volatile administrative legacy and the borders that were repeatedly constructed anew plays into the hands of politicians who combine these features in order to put forth their argument about the need to protect the Polish nation. It is here that present-day borders are burdened with historical 'phantoms'.

\section{Corresponding author}

Jasper Klomp University of Ljubljana, Department of History, Aškerčeva cesta 2, 1000 Ljubljana, Slovenia. E-mail: jasperklomp1@gmail.com.

${ }^{64}$ Grandits, Gewandelte Wissensordnungen, 165. 